\title{
Effect of the economic outturn on the cost of debt of an industrial enterprise
}

\author{
Marek Vochozka ${ }^{1,}$ \\ ${ }^{1}$ Institute of Technology and Business, School of Expertness and Valuation, Okružní 517/10, 37001 \\ České Budějovice, Czech Republic
}

\begin{abstract}
The cost of debt is referred to as the key factor determining profitability. It is a decisive factor in decision making of the management, especially in strategy development. The purpose of this paper is to establish the relationship between the volume of debt and the economic outturn of industrial enterprises. Using artificial neural networks, the relationship between interest costs and three profit categories is examined. Data of 5622 Czech processing enterprises in the years 2015-2017 are used. Multilayer perceptron neural networks and neural networks of basic radial functions are used for processing. A total of 10,000 neural structures are generated for each cost-interest relationship and the corresponding profit, of which 5 are retained, showing the best results. The results indicate that in all cases of profit there is no dependence between the interest and the amount of profit generated. Profiting companies do not get debt cheaper than other businesses.
\end{abstract}

Key words: economic outturn, debt, artificial neural networks, profit

\section{Introduction}

Capital refers to financial assets or financial values of assets such as cash and cash held on deposit accounts, as well as tangible machines and production facilities used at different workplaces, for example in factories. In addition, capital includes equipment such as buildings used to produce and store manufactured goods [1]. The company's financial management is a decision-making process with the sole purpose of achieving the company's main goal. Estimates of capital costs are therefore of great importance in this area [2]. The use of information on capital costs in the company's decision-making process is closely related to the assessment of the company's financial management using market value added [3].

Capital costs have a major impact on the key decisions of the Board of Directors on the scope of investment plans, the setting of objectives, the growth of capital, the creation of an optimal capital structure and other areas of financial management in the company such as capital budgets, takeover processes, etc. It is also a parameter in the calculation of return on investment and a useful tool for a number of other analyses [4].

\footnotetext{
*Corresponding author: vochozka@mail.vstecb.cz
} 
The average capital cost of an enterprise can be expressed using the WACC model, the weighted average cost of capital. The weighted average cost of capital consists of part of the cost of the debt and partly of the cost of equity [5].

The total cost of capital in \% can be expressed as follows [5]:

$$
\begin{gathered}
W A C C=k d *(1-t) * D / C+k e+ \\
E / C
\end{gathered}
$$

Where:

$\mathrm{kd}=$ costs of debt,

$\mathrm{ke}=$ equity costs,

$\mathrm{t}=$ rate of profit tax (per decimal number),

$\mathrm{D}=$ market value of debt,

$\mathrm{C}=$ value of total capital,

$\mathrm{E}=$ market value of equity.

Debt costs are a key component for managerial decision-making and are an important factor determining profitability. Debt costs determine the availability of capital for future investments and the profitability of current operations. Debt costs are therefore a decisive factor in strategy development [6]. The cost of debt (debt costs) in \% can be expressed as follows [7].

$$
K d=r *(1-t)
$$

Where:

$r=$ contractual interest rate,

$\mathrm{t}=$ the marginal tax rate for businesses.

Each capital is valued at its cost, so it has its own costs. For example, we can consider the return of equity (E) as the desired return of the company's owners. The interest on the loan is stated as the cost of debt. Equity is generally referred to as more expensive capital than debt [8].

We can express the cost of equity in $\%$ as follows [9]:

$$
r e=r f+\beta *(r m-r f)
$$

Where:

$\mathrm{rf}=$ risk-free interest rate,

$\beta=$ relative risk coefficient,

$\mathrm{rm}=$ average return on the capital market.

The relationship between the volume of debt and the economic outturn will be examined in this paper by Artificial Neural Networks (ANNs). The concept of a neural network has been developed in biology and psychology, but its use goes to other areas, such as business and economics. At present, ANNs are widely used to address possible future problems. ANNs try to copy processes in the human brain and nervous system using computer devices [10].

The big advantage is that ANN's relationships may not be determined in advance because this method itself creates relationships through the learning process. They are especially valuable where inputs are highly correlated, missing, or there are non-linear systems [11]. Artificial neural networks are currently extensively used in various technical 
applications and become a common method for providing various solutions in optimization, regression and problem estimation [12]. Despite their simplified design, they have the ability to mimic human qualities in problem solving through education and generalization [13].

The neural network consists of an input layer, an output layer, and one or more intervening layers, also referred to as hidden layers [14]. Hidden layers can capture a nonlinear relationship between variables. Each layer consists of multiple neurons that are attached to the neurons in the adjacent layers. These networks contain many mutually interacting nonlinear neurons in several layers. They can capture relatively complex phenomena [15].

The purpose of this paper is to establish the relationship between the volume of debt and the economic outturn of industrial enterprises.

We also set the hypothesis to support the achievement of the goal: The cost of debt depends on the economic outturn.

\section{Data and methods}

The paper examines the data of 5622 enterprises operating in the manufacturing industry in the Czech Republic between 2015 and 2017. The data comes from the Albertina database. Complete statements of the financial statements of all these companies are available. For the analysis, however, only some data are important, namely the amount paid using debt (interest expense), operating profit, interest and tax profit and pre-tax profit. We will examine the relationship between cost and three profit categories.

Operating profit (economic outturn) relates to the enterprise's core business. It is possible to influence it managerially and its creation directly affects the future existence of the company.

Profit before Interest and Tax (EBIT) is the so-called Managerial Profit Category. Its aim is to reduce the impact of businesses that are not highly influenced by corporate interests - cost and corporation tax.

Profit before tax (EBT) is also a profit category that attempts to shield the impact of corporate income tax on its interpretation.

The tool by which we examine the relationship will be neural networks. Specifically, they will be Multilayer Perceptron Networks (MLP) and Neural Networks of Basic Radial Functions (RBFs). We will be using the program Statistica by DELL in version 12. The data will be imported from the MS Excel file, which is the output of the Albertina database. The software will use Data Mining - neural networks. In particular, we will need a part called Regression. First, we select data - it will always be a cost-dependent variable. As an independent variable, we understand the selected profit category. Subsequently, we divide the data into three sets: training, testing and validation. The ratio will be 70:15:15. On the set of training we will look for suitable neural networks that describe the relationship between the two variables. On the other two datasets, we then verify that the neuronal structures found are adequate and faithfully describe the situation.

We will generate 10,000 neural structures, of which we will keep the 5 best in terms of performance and error. For MLP we use a minimum of 2 and a maximum of 8 neurons in a hidden layer. We use the following functions to activate the inner neuron layer as well as to activate the outer layer of neurons:

- Identity,

- Logistics function,

- Hyperbolic tangents,

- Exponential function,

- Sine function. 
In the case of RBF, at least 21 and up to 30 neurons will be hidden in the hidden layer. In order to confirm or refute the established hypothesis, we determine that the variables are in relation if their correlation coefficient is at least 0.7 .

\section{Results}

As has been determined by the methodology, we have dealt with the relationship between cost and interest categories. These were used by three. This will correspond to the breakdown of the results obtained.

\subsection{Operating profit (economic outturn)}

Table 1 provides basic statistical characteristics of the input variables in the breakdown between the training, texting, and validation data sets. At the same time, the characteristics for the whole set are given.

Table 1. Data statistics - Operating profit and interest expense

\begin{tabular}{|l|r|r|}
\hline \multicolumn{1}{|c|}{ Characteristics } & $\begin{array}{c}\text { Operating outturn - } \\
\text { ths. CZK }\end{array}$ & Price of bank loans \\
\hline Minimum (Training) & -507427 & 0.000147 \\
\hline Maximum (Training) & 7356017 & 0.984321 \\
\hline Average (Training) & 16102 & 0.084567 \\
\hline Standard Deviation (Training) & 145721 & 0.117928 \\
\hline Minimum (Testing) & -211884 & 0.000702 \\
\hline Maximum (Testing) & 765533 & 0.947368 \\
\hline Average (Testing) & 12590 & 0.080872 \\
\hline Standard Deviation (Testing) & 49279 & 0.119176 \\
\hline Minimum (Validation) & -190930 & 0.000164 \\
\hline Maximum (Validation) & 965185 & 0.878788 \\
\hline Average (Validation) & 11370 & 0.073653 \\
\hline Standard deviation (Validation) & 80721 & 0.098862 \\
\hline Minimum (Overall) & -507427 & 0.000147 \\
\hline Maximum (Overall) & 7356017 & 0.984321 \\
\hline Average (Overall) & 14866 & 0.082377 \\
\hline Standard Deviation (Overall) & 124833 & 0.114635 \\
\hline
\end{tabular}

The operating result is expressed in thousands of CZK. The price of bank loans, or rather of paid debt is expressed by index. For example, it is clear from the table that the highest interest paid is up to $98.4 \%$. Average interest is then almost $8.24 \%$.

10,000 neural structures were generated. Of these, five of the best characteristics were retained. These are listed in Table 2. 
Table 2. Overview of preserved neural networks (operating profit)

\begin{tabular}{|l|l|c|c|c|c|c|c|c|c|c|c|}
\hline & $\begin{array}{c}\text { Network } \\
\text { name }\end{array}$ & $\begin{array}{c}\text { Train. } \\
\text { Perf. }\end{array}$ & $\begin{array}{c}\text { Test. } \\
\text { Perf. }\end{array}$ & $\begin{array}{c}\text { Valid. } \\
\text { Perf. }\end{array}$ & $\begin{array}{c}\text { Train. } \\
\text { error }\end{array}$ & $\begin{array}{c}\text { Test. } \\
\text { error }\end{array}$ & $\begin{array}{c}\text { Validat. } \\
\text { error }\end{array}$ & $\begin{array}{c}\text { Train. } \\
\text { algor. }\end{array}$ & $\begin{array}{c}\text { Error } \\
\text { function }\end{array}$ & $\begin{array}{c}\text { Hidden } \\
\text { layer } \\
\text { act. }\end{array}$ & $\begin{array}{c}\text { Output } \\
\text { act. } \\
\text { funct. }\end{array}$ \\
\hline 1 & $\begin{array}{l}\text { RBF } \\
1-24-1\end{array}$ & 0.06914 & 0.04175 & 0.15998 & 1759133 & 2079149 & 1349410 & RBFT & Sum.qt. & Gauss & Identity \\
\hline 2 & $\begin{array}{l}\text { RBF } \\
1-25-1\end{array}$ & 0.06666 & 0.03323 & 0.15737 & 2389524 & 2180104 & 2533730 & RBFT & Sum.qt. & Gauss & Identity \\
\hline 3 & $\begin{array}{l}\text { RBF } \\
\text { 1-28-1 }\end{array}$ & 0.12625 & 0.04290 & 0.16755 & 2147330 & 2203807 & 2274527 & RBFT & Sum.qt. & Gauss & Identity \\
\hline 4 & $\begin{array}{l}\text { RBF } \\
1-21-1\end{array}$ & 0.07213 & 0.04567 & 0.14818 & 5610786 & 5981590 & 5496185 & RBFT & Sum.qt. & Gauss & Identity \\
\hline 5 & $\begin{array}{l}\text { RBF } \\
1-22-1\end{array}$ & 0.01193 & 0.01018 & 0.21063 & 74510380 & 55042374 & 88967422 & RBFT & Sum.qt. & Gauss & Identity \\
\hline
\end{tabular}

The table shows that all retained networks use the RBF architecture. All of them also use the Gauss curve to activate the hidden neuronal layer and then to identify the external layer of the neurons.

However, network performance is scarce. This is illustrated by table number 3 .

Table 3. Correlation coefficients of preserved neural networks (operating profit)

\begin{tabular}{|l|c|r|r|}
\hline \multirow{2}{*}{$\begin{array}{l}\text { Neuron } \\
\text { network }\end{array}$} & \multicolumn{3}{|c|}{ Price of bank loans } \\
\cline { 2 - 4 } 1.RBF 1-24-1 & \multicolumn{1}{|c|}{ Training } & Testing & \multicolumn{1}{c|}{ Validation } \\
\hline 2.RBF 1-25-1 & 0.069142 & 0.04175 & 0.159975 \\
\hline 3.RBF 1-28-1 & 0.066663 & 0.033227 & 0.157366 \\
\hline 4.RBF 1-21-1 & 0.126247 & 0.042897 & 0.167553 \\
\hline 5.RBF 1-22-1 & 0.072133 & 0.04567 & 0.148184 \\
\hline
\end{tabular}

The performance of neural networks is measured by the correlation coefficient. The table provides correlation coefficients for all sets of preserved networks. We are ideally searching for a network that has a correlation coefficient of 0.7 and higher and ideally similar performance in the training, test and validation data sets. However, this does not show any of the preserved neural networks. Given the performance of individual networks, we can say that there is no dependence between operating profit and interest expense (the cost of debt).

A very important characteristic is the residue. Ideally, there is no prediction of any residues. In this case, it means the minimum and maximum long distance predictions from reality. Thus, we can say that in the category of operating profit, the hypothesis was reversed.

\subsection{Profit before interest and taxes (EBIT)}

Table 4 provides basic input statistics. 
Table 4 Data statistics - EBIT and cost interest

\begin{tabular}{|l|r|r|}
\hline & EBIT & Price of bank loans \\
\cline { 2 - 3 } & Input variable & Output (goal) \\
\hline Minimum (Training) & -508543 & 0.000147 \\
\hline Maximum (Training) & 7266527 & 0.984321 \\
\hline Average (Training) & 16152 & 0.084567 \\
\hline Standard Deviation (Training) & 146454 & 0.117928 \\
\hline Minimum (Testing) & -88568 & 0.000702 \\
\hline Maximum (Testing) & 769040 & 0.947368 \\
\hline Average (Testing) & 13316 & 0.080872 \\
\hline Standard deviation (Testing) & 55622 & 0.119176 \\
\hline Minimum (Validation) & -202041 & 0.000164 \\
\hline Maximum (Validation) & 916084 & 0.878788 \\
\hline Average (Validation) & 10906 & 0.073653 \\
\hline Standard deviation (Validation) & 71125 & 0.098862 \\
\hline Minimum (Overall) & -508543 & 0.000147 \\
\hline Maximum (Overall) & 7266527 & 0.984321 \\
\hline Average (Overall) & 14940 & 0.082377 \\
\hline Standard deviation (Overall) & 125764 & 0.114635 \\
\hline
\end{tabular}

The interest (or the cost of the debt) is the same as table 1 . The change is then in the column marked EBIT, which offers the second variable to be examined. For comparison, we select one variable, the total is lower for EBIT than for operating profit. It can be deduced that the particular firm in question (certainly the same business) generated a loss of financial, (a) or extraordinary activity.

The stored networks are in Table 5. Again, of the 10000 generated networks, the five best characteristics were left.

Table 5. Overview of preserved neural networks (EBIT)

\begin{tabular}{|c|c|c|c|c|c|c|c|c|c|c|c|}
\hline & $\begin{array}{c}\text { Network } \\
\text { name }\end{array}$ & $\begin{array}{l}\text { Train. } \\
\text { perf. }\end{array}$ & $\begin{array}{l}\text { Test. } \\
\text { perf. }\end{array}$ & $\begin{array}{l}\text { Valid. } \\
\text { perf. }\end{array}$ & $\begin{array}{l}\text { Train. } \\
\text { error }\end{array}$ & $\begin{array}{l}\text { Test. } \\
\text { error }\end{array}$ & $\begin{array}{c}\text { Validat. } \\
\text { error }\end{array}$ & $\begin{array}{l}\text { Train. } \\
\text { algor. }\end{array}$ & $\begin{array}{c}\text { Error } \\
\text { function }\end{array}$ & $\begin{array}{c}\text { Hidden } \\
\text { layer } \\
\text { act. }\end{array}$ & $\begin{array}{l}\text { Output } \\
\text { act. } \\
\text { funct. }\end{array}$ \\
\hline 1 & $\begin{array}{r}\text { RBF } \\
1-23-1\end{array}$ & 0.11208 & 0.056685 & 0.13056 & 827743 & 935330 & 890193 & RBFT & Sum.qt. & Gauss & Identity \\
\hline 2 & $\begin{array}{r}\mathrm{RBF} \\
1-21-1\end{array}$ & 0.090216 & 0.061057 & 0.127725 & 7780315 & 7752146 & 8343863 & RBFT & Sum.qt. & Gauss & Identity \\
\hline 3 & $\begin{array}{r}\mathrm{RBF} \\
1-24-1 \\
\end{array}$ & 0.144422 & 0.066246 & 0.126835 & 1291421 & 1261820 & 1340023 & RBFT & Sum.qt. & Gauss & Identity \\
\hline 4 & $\begin{array}{r}\mathrm{RBF} \\
1-25-1 \\
\end{array}$ & 0.090728 & 0.034356 & 0.142812 & 1016761 & 1115185 & 1045455 & RBFT & Sum.qt. & Gauss & Identity \\
\hline 5 & $\begin{array}{r}\mathrm{RBF} \\
1-22-1\end{array}$ & 0.091924 & 0.089913 & 0.154548 & 830338 & 855661 & 875923 & RBFT & Sum.qt. & Gauss & Identity \\
\hline
\end{tabular}

The result is very similar to operating profit. Again, it is only RBF. To activate the inner layer of neurons, they use Gaussian function, to activate the output layer of neurons identity.

The performance of retained networks is shown in table 6 . 
Table 6. Correlation coefficients of preserved neural networks (EBIT)

\begin{tabular}{|l|c|c|c|}
\hline & \multicolumn{3}{|c|}{ Price of bank loans } \\
\cline { 2 - 4 } & Training & Testing & Validation \\
\hline 1.RBF 1-23-1 & 0.11208 & 0.056685 & 0.13056 \\
\hline 2.RBF 1-21-1 & 0.090216 & 0.061057 & 0.127725 \\
\hline 3.RBF 1-24-1 & 0.144422 & 0.066246 & 0.126835 \\
\hline 4.RBF 1-25-1 & 0.090728 & 0.034356 & 0.142812 \\
\hline 5.RBF 1-22-1 & 0.091924 & 0.089913 & 0.154548 \\
\hline
\end{tabular}

Even for EBIT, net power is very small, albeit slightly better than operating profit. Still, we can not talk about any dependence. Also in this case, the hypothesis was refuted.

\subsection{Profit before tax (EBT)}

Table 7 lists the statistical characteristics of the input variables.

Table 7. Data statistics - EBT and cost interest

\begin{tabular}{|l|r|r|}
\hline \multicolumn{1}{|c|}{ Characteristics } & $\begin{array}{c}\text { Profit before tax (+/-) } \\
\text { - ths. CZK }\end{array}$ & $\begin{array}{c}\text { Cost of debt } \\
\text { resources }\end{array}$ \\
\hline Minimum (Training) & -587766 & 0.000051 \\
\hline Maximum (Training) & 7137185 & 0.195682 \\
\hline Average (Training) & 14984 & 0.018553 \\
\hline Standard deviation (Training) & 143964 & 0.018175 \\
\hline Minimum (Testing) & -91844 & 0.000144 \\
\hline Maximum (Testing) & 760073 & 0.124312 \\
\hline Average (Testing) & 12310 & 0.01737 \\
\hline Standard deviation (Validation) & 54257 & 0.015643 \\
\hline Minimum (Validation) & -230073 & 0.00009 \\
\hline Maximum (Validation) & 914086 & 0.131193 \\
\hline Average (Validation) & 9652 & 0.017667 \\
\hline Standard deviation (Validation) & 67963 & 0.017038 \\
\hline Minimum (Overall) & -587766 & 0.000051 \\
\hline Maximum (Overall) & 7137185 & 0.195682 \\
\hline Average (Overall) & 13783 & 0.018243 \\
\hline Standard deviation (Overall) & 123588 & 0.017536 \\
\hline
\end{tabular}

We have recently reviewed the EBT. We select one of the EBT characteristics, namely the maximum. Again, it is probably the same business that generated the maximum value of both EBIT and operating profit. In this case, the maximum is slightly lower (by value of cost interest). However, it is from this value that we can deduce the low indebtedness of the business or the low cost of the debt resources used by it.

Again, 10,000 neural networks were generated. These were retained again. These are listed in Table 8. 
Table 8. Overview of preserved neural networks (EBT)

\begin{tabular}{|l|l|c|c|c|c|c|c|c|c|r|r|}
\hline & $\begin{array}{c}\text { Network } \\
\text { name }\end{array}$ & $\begin{array}{c}\text { Train. } \\
\text { perf. }\end{array}$ & $\begin{array}{c}\text { Test. } \\
\text { perf. }\end{array}$ & $\begin{array}{c}\text { Valid. } \\
\text { perf. }\end{array}$ & $\begin{array}{l}\text { Train. } \\
\text { error }\end{array}$ & $\begin{array}{c}\text { Test. } \\
\text { error }\end{array}$ & $\begin{array}{c}\text { Valid. } \\
\text { error }\end{array}$ & $\begin{array}{c}\text { Train. } \\
\text { algor. }\end{array}$ & $\begin{array}{c}\text { Error } \\
\text { function }\end{array}$ & $\begin{array}{c}\text { Hidden } \\
\text { layer act. }\end{array}$ & $\begin{array}{c}\text { Output act. } \\
\text { funct. }\end{array}$ \\
\hline 1 & $\begin{array}{l}\text { MLP } \\
1-2-1\end{array}$ & 0.25249 & 0.21798 & 0.25279 & 0.00016 & 0.00012 & 0.00012 & $\begin{array}{r}\text { BFGS } \\
9999\end{array}$ & Sum.qt. & Logistic & Logistic \\
\hline 2 & $\begin{array}{l}\text { MLP } \\
1-2-1\end{array}$ & 0.23701 & 0.20376 & 0.23193 & 0.00016 & 0.00012 & 0.00013 & $\begin{array}{r}\text { BFGS } \\
10000\end{array}$ & Sum.qt. & Logistic & Exponential \\
\hline 3 & $\begin{array}{l}\text { MLP } \\
\text { 1-2-1 }\end{array}$ & 0.25352 & 0.21917 & 0.25520 & 0.00016 & 0.00012 & 0.00012 & $\begin{array}{r}\text { BFGS } \\
4640\end{array}$ & Sum.qt. & Logistic & Logistic \\
\hline 4 & $\begin{array}{l}\text { MLP } \\
1-2-1\end{array}$ & 0.23639 & 0.20013 & 0.22591 & 0.00016 & 0.00012 & 0.00013 & $\begin{array}{r}\text { BFGS } \\
462\end{array}$ & Sum.qt. & Tang & Logistic \\
\hline 5 & $\begin{array}{l}\text { MLP } \\
1-2-1\end{array}$ & 0.24321 & 0.21050 & 0.23675 & 0.00016 & 0.00012 & 0.00012 & $\begin{array}{r}\text { BFGS } \\
5034\end{array}$ & Sum.qt. & Logistic & Logistic \\
\hline
\end{tabular}

The result differs from the previous two categories of profits. Only MLPs are now preserved. To activate the hidden layer of neurons they use a logistic function, in one case a hyperbolic tangent. The logic function is used to activate the outer layer of the neurons, only exponential functions. All networks were created using the Quasi-Newton algorithm (but it differs in its variant).

Table 9 shows the performance of individual preserved networks.

Table 9. Correlation coefficients of preserved neural networks (EBT)

\begin{tabular}{|l|r|r|r|}
\hline & \multicolumn{3}{|c|}{ Cost of debt resources } \\
\cline { 2 - 4 } & \multicolumn{1}{|c|}{ Training } & \multicolumn{1}{c|}{ Testing } & \multicolumn{1}{c|}{ Validation } \\
\hline 1.MLP 1-2-1 & 0.252488 & 0.217982 & 0.252787 \\
\hline 2.MLP 1-2-1 & 0.237011 & 0.203762 & 0.231934 \\
\hline 3.MLP 1-2-1 & 0.253517 & 0.219174 & 0.255196 \\
\hline 4.MLP 1-2-1 & 0.236392 & 0.20013 & 0.225914 \\
\hline 5.MLP 1-2-1 & 0.243214 & 0.210502 & 0.23675 \\
\hline
\end{tabular}

Correlation coefficients are more than double that of EBIT. They are even similar to each set of data. Nevertheless, they are far below the required levels of 0.7. Even in this case we can say that the studied quantities are indifferent to each other. Even in this case, the hypothesis was refuted.

\section{Conclusion}

The aim of this paper was to determine the relationship between the volume of debt and the economic outturn of industrial enterprises.

A hypothesis was also set to support the rate of completion of the goal.

The relationship of the cost of debt and profit was analyzed using three profit categories - operating profit, EBIT and EBT. In theory, it was possible to believe that the relationship between profit and the amount of interest exists. Theoretically, it could be assumed that the higher the economic outturn, the lower the interest on the lent debt. We could have guessed that a successful profitable firm would have easier access to debt. At the same time, the cost of debt will be lower for such a company, as the company has lower credit risk. However, the correlation has not been confirmed. In all cases of profit we can state that there is no dependence between interest and the amount of profit generated.

Profiting companies do not get debt cheaper than other companies (those that do not generate profit or even generate a loss). 


\section{References}

1. V. Wiegel, The prospectus directive and the prospectus ordinance is a dogmatic, economic and comparative law [Die Prospektrichtlinie und Prospektverordnung eine dogmatische, ökonomische und rechtsvergleichende]. In: Writings on European and International Private, Banking and Commercial Law [Schriften zum Europäischen und Internatinalen Privat, Bank und Wirtschaftsrecht], Berlin, De Gruyter Recht, (2008)

2. P. Šuleř, Optimizing the capital structure of the company to maximize its profits by using neural networks on the example of building companies. Mathematical Modelling in Economics [Математичне моделювання в економіці], 7(3-4), (2016)

3. J. Bertomeu, E. Cheynel, Disclosure and the Cost of Capital: A Survey of the Theoretical Literature. Abacus-A Journal of Accounting Finance and Business Studies, 52(2), 221-258 (2016)

4. A. Michalak, The Cost of Capital in the Effectiveness Assessment of Financial Management in a Company. Oeconomia Copernicana, 7(2), 317-329 (2016)

5. M. Z. Frank, T. Shen, Investment and the weighted average cost of capital. Journal of Financial Economics, 119(2), 300-315 (2016)

6. M. Mirea, A. V. S. Comanescu, Financing decision based on the weighted average cost of capital. Proceedings of the International Economic Conference on Integrative Relations between the European-Union-Institutions-and-the-Member-States, Sibiu, Romania, 265-269 (2008)

7. T. Lindner, J. Muellner, J. Puck, Cost of Capital in an International Context: Institutional Distance, Quality, and Dynamics. Journal of International Management, 22(3), 234-248 (2016)

8. A. Kumar, R. Sharma, Financial management: Theory and Practice. Vishla Enclave, New Delhi: Atlantic Publishers \& Distributors Pvt Ltd, (2001)

9. M. Abudy, S. Benninga, E. Shust, The cost of equity for private firms. Journal of Corporate Finance, 37(2), 431-443 (2016)

10. J. Dzuričková, R. Fabinyová, B. Mihalčová, The Opportunity Cost of Equity Capital. Procedia Economics and Finance, 23(2), 1492-1498 (2015)

11. D. Enke, S. Thawornwong, B.C. Fidan, The use of data mining and neural networks for forecasting stock market returns. Expert Systems with Applications, 29(4), 927-940 (2005)

12. H. T. Pao, A comparison of neural network and multiple regression analysis in modeling capital structure. Expert Systems with Applications, 35(3), 720-727 (2008)

13. M. Vochozka, Z. Rowland, V. Stehel, P. Šuleř, J. Vrbka, Cost modelling of the company using neural networks [Modelování nákladů podniku pomocí neuronových sití]. $1^{\text {st }}$ ed. Czech Republic, České Budějovice: Institute of Technology and Business (2016)

14. H. Altun, A. Bilgil, B.C. Fidan, Treatment of multi-dimensional data to enhance neural network estimators in regression problems. Expert Systems with Applications, 32(2), 599-605 (2007)

15. Z. Rowland, J. Vrbka, Optimization of a company's property structure aiming at maximization of its profit using neural networks with the example of a set of construction companies. Mathematical Modelling in Economics [Математичне моделювання в економіці], 7(3-4), (2016) 
16. F. M. Tseng, H.-Ch. Yu, G. H. Tzeng, Combining neural network model with seasonal time series ARIMA model. Technological Forecasting and Social Change, 69(1), 7187 (2002) 